Vlado Belaj, Ph.D.*

Full Professor, Faculty of Law, University of Osijek

Croatia

Ivan Belaj, Mag. iur,

Lecturer, Polytechnics "Lavoslav Ružička”, Vukovar

Croatia
ПРЕГЛЕДНИ НАУЧНИ РАД

doi:10.5937/zrpfni1879351В

\title{
CONTRIBUTION OF THE INJURED PARTY TO SUSTAINED DAMAGE
}

UDK: 347.51

Рад примљен: 30.09.2018.

Рад прихваћен: 02.11.2018.

\begin{abstract}
Contribution of the injured party to his/her damage or shared responsibility for damages implies that the damages occurred not only due to offender's actions but that the injured party also contributed to the sustained damage. This fact should be taken into account when determining the amount of damages, i.e. to share responsibility for damage between the injured party and the offender. Roman law did not recognize shared responsibilities for damage, and the contribution of the injured party to sustained damage was regulated only after the adoption of the most important civil codes. Legal theories and laws of certain states use different terms for shared responsibility for damages. Another important issue is whether the injured party's responsibility is based on fault or contribution to the occurrence of damage. This paper investigates legal and theoretical assumptions of shared responsibility for damage in comparative law, with reference to the most significant civil regimes in the world and civil law regimes in some former SFRY states.
\end{abstract}

Keywords: damages, offender, the injured party, quilt, injured party's contribution, responsibility for damages, damage repairs.

\footnotetext{
*vbelaj@pravos.hr

ibelaj@vevu.hr

${ }^{* *}$ This paper was presented at the International Scientific Conference "Law in the context of addressing the Challenges of the Contemporary World", held at the Faculty of Law, University of Niš, on $13^{\text {th }}-14^{\text {th }}$ April 2018.
} 


\section{Introduction}

Contribution of the injured party to his/her damage or shared responsibility for the damage means that, besides the offender, the injured party has also contributed in some way to the occurrence of damage. The basic question of shared responsibility for damage is whether the injured party's co-responsibility for damages is based on his/her fault or some other factor.

Regarding shared responsibility for damage, some other issues are also significant, such as:

1. Can a delinquently incapable individual as an injured person receive the reduction of amount of damage compensation?

2. What is the impact on damage compensation of the fact that the damage was committed by the assistant or the representative of the injured party?

3. Is it relevant if the injured person placed himself/herself in danger?

In Roman law, there was no shared responsibility for damage. Such responsibility for damage did not exist even in reciprocal Roman law.

Shared responsibility for damage first appeared in the civil law of the $19^{\text {th }}$ century, but not in the French Civil Code as the first historical source of civil law. Shared responsibility for damage was created by the need to better regulate the increased number of cases related to damage in contemporary social circumstances. Under these circumstances, it was not possible to ignore the fact that the injured party may in some way contributed to the occurrence of damage. In the observed foreign legislation, as well as in the legislations of the states formed after the dissolution of the former SFRY, it is evident that shared responsibility for damage is regulated with very few legal provisions of principal nature. Therefore, case law has a complex task in applying and interpreting these legal rules. Court practice also has a more important task to create quality solutions in terms of shared responsibility for damage.

An injured party can contribute to the occurrence of damage through active behaviour, passive behaviour or through omission. In addition, the injured party's contribution to sustained damage may consist of failing to take actions to limit or completely eliminate the effects of the resulting damage.

\section{Shared responsibility for damage in comparative law}

\subsection{Austria}

The Austrian Civil Code of 1811 (Allgemeines Bürgerliches Gesetzbuch) providesin paragraph 1304 that there is shared responsibility for damage. According 
to these provisions, "if the injured party bears quilt for any damage, then the injured party shall bear the damages in proportion to the offender, and if the proportion cannot be determined, the injured party shall be responsible for the same amount of damages". In Austrian jurisprudence and legal literature on shared responsibility for damage (for example, Koziol, 1986: 236; Rummel, 1992: 364), the most commonly used terms are the injured party's complicity and the injured party's co-responsibility (to a smaller extent).There must be a causal link between the injured party's behaviour and the sustained damage, so that the damages can be counted against the injured party as well (Koziol, 1986: 237). A victim's innocence (delict capacity) is required to be linked to the injured party's fault (guilt).However, in exception, co-responsibility for damage can possibly be attributed to children under the age of seven and to feeble-minded individuals if their behaviour differs from "the most basic precautionary measures". ${ }^{1}$ This means that in most cases mentally incompetent individuals cannot be held responsible for damage.

In the cited paragraph, the Austrian Civil Code mentions the injured party's fault (guilt) as a prerequisite for his/her involvement in damage repairs. However, the theoretical part explains that the injured party's guilt is not guilt in the full technical sense of the word. Thus, there is no need to prove the unlawfulness of the injured party's behaviour; it is sufficient to prove the injured party's negligence for his/her own goods (Koziol, 1986: 236, 237).

According to the cited paragraph of the Austrian Civil Code, if there is shared responsibility for damage, then it is necessary to determine the share of responsibility for damage between the offender and the injured party; if it is not possible, the offender and the injured party will share the liability equally and bear the same amount of damages. In this case, the guilt of both offender and the injured party is taken into account, i.e. the injured party would not be responsible for damage if the offender acted with intent (dolus) or with utter negligence (culpa lata).The injured party's guilt is also observed, and if he/she acted intentionally, while the offender only acted with negligence, then the offender would not bear any responsibility. In the case of the same type or degree of guilt, shared responsibility for damage would certainly exist; thus, a part of damage repairs would be borne by both the offender and the injured party.

\subsection{France}

The French Civil Code of 1804 (Code civil) does not contain provisions on shared responsibility for damage. However, some other regulations contain provisions on shared responsibility for damage, such as the Labour Accidents Act, the Social Security Act, and the Commercial Code.

1 compare ZVR 1988, 46. 
In French jurisprudence and legal literature (for example, Planiol-Ripert, 1952: 520), the term injured party's mistakes used for shared responsibility for damage. The injured party's behaviour must be the co-cause of the sustained damage; thus, without such behaviour, no damages would have incurred (MazeaudTunc, 1970: 1460). The injured party's behaviour is the sole cause of damage if such behaviour was unpredictable and inevitable for the offender. The injured party's behaviour that co-caused the damages has to be unlawful in order to induce shared responsibility for damage. The injured party's behaviour that has caused the damage must be unlawful in order to share the responsibility for damage (Mazeaud-Tunc, 1970: 1467). The law does not set the proportion of damages borne by the offender and the injured party; hence, the court assesses the damage and awards damages by taking into account all the circumstances of the case. In particular, the type and degree of guilt of both the offender and the injured party are taken into account.

\subsection{Germany}

In the German legal literature (Larenz, 1982: 494) and jurisprudence, the terms injured party's co-responsibility, injured party's co-causality and injured party's co-responsibility are used to indicate the injured party's contribution to his/her own damage. The German Civil Code of 1896 (Bürgerliches Gesetzbuch) states in paragraph 254: "If the injured party's guilt was involved in the occurrence of damage, the obligation to compensate and the scope of the remuneration are to be given depending on the circumstances, in particular whether the damage was predominantly caused by one side or the other. This is also true if the injured party's quilt is limited to failing to warn the debtor of the danger of causing a particularly serious damage for which the debtor did not know nor had to know, or failing to prevent or reduce the damage". These provisions may be criticized in the nomotechnical sense and in terms of content. Namely, it would be better not to state that the injured party's guilt was involved in the occurrence of damage, but that the injured party participated in the sustained damage and that a certain level of fault lies with him/her. In addition, it is unclear which circumstances the right to compensation for damage depends on, i.e. the scope of compensation. It is apparent from the quoted provisions that shared responsibility for damage does not only relate to the active behaviour of the injured party at the time of sustaining damage but also to his/her failure to prevent or reduce the damage. The German Civil Code does not regulate whether the mental capacity of the injured party is a presumption of shared responsibility for damage, and that issue is left to the court's case law.

Paragraph 278 of the German Civil Code reads: "The debtor is responsible for the guilt of his/her legal representative and for the persons serving in the fulfilment 
of his/her obligations to the same extent as for his own guilt." Thus, the debtor will also be responsible for the sustained damage, even in case of shared responsibility, regardless of fact that his/her legal representative or assistant is guilty.

The injured party's fault referred to in German civil law does not mean guilt in the full meaning of the word; in fact, it means a certain lapse of the injured party who contributed to the sustained damage.

Shared responsibility for damage also exists in case of delinquent and contractual responsibility for damage. The injured party's behaviour must have the character of a co-causefor incurred damage, which may include both active and passive behaviour.

\subsection{Russia}

In Russia, a term mixed responsibility is used to designate shared responsibility. Article 404 of the Civil Code of the Russian Federation of 1994 states: "If the failure to fulfil obligations or the negligent fulfilment of the obligation was caused by the fault of both parties, the court appropriately limits the amount of the debtor's responsibility. The court is also empowered to limit the amount of the debtor's responsibility when the creditor has contributed to the increase of the incurred damage or failed to take appropriate measures for its reduction whether by intent, negligence, failure to fulfil or inappropriate fulfilment of obligations." It is apparent that shared responsibility for damage only refers to contractual and not to delinquent responsibility for damage. Shared responsibility is not applied if the injured party is delinquently incapable.

\subsection{Switzerland}

In Switzerland, shared responsibility for damage is regulated by the Obligations Act of 1911 (Obligationen recht), which states in Article 44, paragraph 1, as follows: "If the injured party has agreed to a harmful action or there are circumstances for which he/she is responsible, and which have contributed to the creation or increase of damages, or the position of the person responsible for the remuneration is otherwise difficult, the judge may reduce the remuneration obligation or completely abolish it". As can be seen in the Obligations Act, the term guilt is not mentioned at all. But, it is mentioned in the context of shared responsibility for damage in court practice and legal literature.

The injured party's coercion (Tuhr, 1974: 106) and the injured party's own guilt (Keller, 1993: 126) are the terms used in the Swiss legal literature and the jurisprudence for shared responsibility for damage. Other regulations also regulate shared responsibility for damage, and they are applied as a lex specialis 
for certain areas, such as: the Railway Law, the Road Traffic Act, and the Electrical Appliances Act. The injured party's guilt is used in these regulations but it is not treated as guilt in the true or the technical sense since there is no legal obligation to protect oneself from harm. The injured party's co-responsibility for damage presumessanity, but court practice has accepted the standpoint that the injured party who is not sane also bears responsibility if imposed by equity.

\section{Shared responsibility for damage in regulations of some former SFRY states and the Republic of Croatia}

Shared responsibility for damage is also applied in the areas of delinquent and contractual responsibility for damage.

In the observed regulations of the former SFRY states, the provisions on shared responsibility for damage were taken from the former Federal Obligation Relations Act ${ }^{2}$, which was applicable in the entire SFRY territory. Thus, nowadays, the Obligation Relations Acts of the Republic of Serbia ${ }^{3}$ (Art. 192), Republic of Montenegro ${ }^{4}$ (Art. 199), and the Federation of Bosnia and Herzegovina and Republika Srpska ${ }^{5}$ (Art. 192) contain the following provision on shared responsibility for damage: "An injured party who has contributed to the occurrence of damage or has caused the damage to be greater than it would be otherwise, is entitled only to a proportionally reduced compensation. When it is impossible to determine which part of the damage stems from the injured party's action, the court will award compensation taking into account the circumstances of the case." This provision envisages delict responsibility for shared responsibility for damage.

The Obligation Relations Act of the Republic of Croatia ${ }^{6}$ contains almost identical provisions in Art.1092, which reads: "An injured party who has contributed to the occurrence of damage or has caused the damage to be greater than it would be otherwise, is entitled only to a proportionally reduced compensation. When it is impossible to determine which part of the damages stems from the injured party's action or omissions, the court will award compensation taking into account the circumstances of the case". The only difference between the Croatian Obligation Relations Act and obligation relations acts of the Republic

2 Official Gazette of SFRJ no.29/1978, 39/1985, 46/1985, 45/1989, 57/1989; Official Gazette no.53/1991, 73/1991, 3/1994, 111107/1995, 7/1996, 91/1996, 112/1999, 88/2001, 35/2005.

3 Official Gazette of SRJ no.31/1993.

4 Official Gazette of Montenegro, no.27/2008, 4/2011, 22/2017.

5 Official Gazette of SFRJ no.29/1978, 39/1985, 46/1985, 45/1989, 57/1989; Official Gazette of BIH no. 2/1992, 13/1993, 13/1994; Official Gazette of Republika Srpska no. 17/1993, 3/1996.

6 Official Gazette no.35/2005, 41/2008, 125/2011, 78/2015, 29/2018. 
of Serbia, the Federation of Bosnia and Herzegovina, the Republika Srpska, and the Republic of Montenegro is the fact thatthe injured party's conduct may also entail an omission, in case of inability to determine the damage. These provisions relate to delinquent responsibility for damage.

In the use of this institute, there is a significant difference between the Obligation Relations Act of the Republic of Croatia and the former SFRY Federal Obligation Relations Act and the Obligation Relations Acts of the Republic of Serbia, the Republic of Montenegro, the Federation of Bosnia and Herzegovina, and the Republika Srpska. Namely, the Croatian Obligation Relations Act uses in the subtitle of an article regulating this type of responsibility for damage the term "contribution of the injured party to his/her own damages", while all other aforementioned acts use the term "shared responsibility". The term shared responsibility is not adequate since the injured party cannot be legally responsible for himself/herself. "The responsibility of a responsible person does not diminish, nor is it shared with the injured party, but his/her obligation to compensation is reduced by a certain amount, compared to the total amount of damage caused. The injured party is not responsible for a part of the damage whose cause or increase can be attributed to the injured party, but he/she is not entitled to compensation for that part of damage. Namely, the injured party does not interfere with the legal right of others, while the violation of their own legal property is not forbidden. Accordingly, the injured party is not responsible for the harm he/she incurred to himself/herself, but suffers the consequences (damage) in the extent to which he/she has contributed to its occurrence or increase. Therefore, it is certainly better to speak of the contribution of the injured party to his/her own damage" (Gorenc, 2005: 1695).

The term shared guilt that was used before the entry into force of the former Federal Obligatory Relations Act was also inappropriate since the injured party cannot be legally guilty towards himself/herself. "The guilt of the injured party that could be the basis for the exclusion of the offender's responsibility is not guilt in the true sense of the word; thus, it is not sanctioned by the law. Namely, this guilt is in a negligent relation to one's own goods, which are, in fact, protected by law, but not against the title holder but against the actions of others. Therefore, the behaviour of the offender becomes legally relevant only at the moment of occurrence of the offender's obligation to compensate for the damage caused to his possessions"(Blagojević, Krulj, 1980: 522). Therefore, it is more acceptable and legally more appropriate to use the term found in the Obligation Relations Act of the Republic of Croatia, which uses the term contribution of the injured party to his/her own damage for this form of responsibility. 
Article 346, paragraphs 4 and 5 of the Obligation Relations Act of the Republic of Croatia also refers to shared responsibility for damage, stating: "A party invoking a contract violation shall take all reasonable measures to reduce the damage caused by such a violation; otherwise, the other party may require a compensation reduction. The provisions of this Article shall also apply appropriately to the non-fulfilment of obligations not arising out of the contract, unless otherwise provided for some of them by this Act". Identical provisions can also be found in the former Federal Obligation Relations Act ${ }^{7}$, the Obligation Relations Act of the Republic of Serbia ${ }^{8}$, the Obligation Relations Act of the Republic of Montenegro, ${ }^{9}$ and the Obligation Relations Act of the Federation of Bosnia and Herzegovina and Republika Srpska ${ }^{10}$. The same subtitle (amount of compensation) may be found in all of these legislative acts. All mentioned provisions relate to contractual responsibility for damage.

Article 347 of the Obligation Relations Act of the Republic of Croatia deals with contractual responsibility for damage, and is bound by shared responsibility for damage; it reads: "When the lender or the person for whom he/she is responsible has contributed to the occurrence of damage or its amount, or has aggravated the borrower's position, the compensation is proportionately reduced". An identical provision exists in the former Federal Obligation Relations Act ${ }^{11}$, the Obligation Relations Act of the Republic of Serbia ${ }^{12}$, the Obligation Relations Act of the Republic of Montenegro, ${ }^{13}$ and the Obligation Relations Act of the Federation of Bosnia and Herzegovina and Republika Srpska ${ }^{14}$. The only difference is that the Croatian Obligation Relations Act contains the subtitle "Reduction of Fees", while all other mentioned laws contain the term "creditor's guilt" in the subtitle. Given that the emphasis here is on the contribution of the creditors as the injured party to their own damages, then it seems inappropriate to use the expression creditor's guilt, which could also be understood as the guilt of the injured party who cannot be legally guilty towards himself/herself. Also, individuals who a creditor is responsible for can contribute to the occurrence of damage, its amount or to the aggravation of the debtor's position. This is primarily the case of

7 Art. 266, paragraphs 4 and 5of the Federal Obligation Relations Act

8 Art. 266, paragraphs 4 and 5of the Obligation Relations Act of the Republic of Serbia

9 Art. 273, paragraphs 4 and 5 of the Obligation Relations Act of the Republic of Montenegro

10 Art. 266, paragraphs 4 and 5 of the Obligation Relations Act of the Federation of Bosnia and Herzegovina and Republika Srpska

11 Art. 267 of the Federal Obligation Relations Act

12 Art. 267 of the Obligation Relations Act of the Republic of Serbia

13 Art. 274of the Obligation Relations Act of the Republic of Montenegro

14 Art. 267 of the Obligation Relations Act of the Federation of Bosnia and Herzegovina and Republika Srpska 
persons who are the injured party's employees and the attorneys of the injured party, and it may also apply to the injured party's guardians who are deprived of their business abilities. In any case, the debtor must himself/herself lodge a claim for the reduction of damage compensation since the court's official duty is not to determine the contribution to damage caused by the creditor and individuals he/she is responsible for.

Regarding contractual responsibility for damage, even if there is shared responsibility, the provisions on extraterritorial damages may also apply. This is stipulated in Article 349 of the Obligation Relations Act of the Republic of Croatia ${ }^{15}$, which reads: "If the provisions of this Section are not otherwise prescribed, the provisions on extrajudicial damages envisaged in this Act shall apply mutatis mutandis to the compensation of this damage."

Shared responsibility for damage does not require the injured party's capacity for judgment or delinquency, but it is sufficient for the injured party to contribute to his/her own damage. In judicial practice, participation of a delinquently incapacitated person in his/her own harm is aligned with the higher force that has been extended to human actions. Previous jurisprudence in the SFRY took the view that shared responsibility requires sanity of the injured party (Kaladić, 2004: 111). However, later, prior to the entry into force of the former Federal Obligation Relations Act, court practice took the standpoint in which a delinquently incompetent person could contribute to the emergence of damage. "In some court decisions, the behaviour of a delinquently incapable person who contributed to the origin of injured party's damage was treated as an inevitable event, a higher force, or a case for which no one was responsible, which meant that the offender was entirely or partially exempt from damage responsibility" (Kaladić, 2004: 111 ).Such a court practice position is also logical because a person who is not capable of reasoning is not responsible for damage he/she has incurred to other persons, and no one can be held responsible for damage he/ she has incurred to himself/herself. This is also confirmed by the provisions of the Obligation Relations Act of the Republic of Croatia on individuals who are not responsible for damage. "A person who, due to mental illness or retarded mental development or for any other reasons, is not capable of reasoning is not responsible for damage he/she causes to others. If anyone causes damages to others in the state of temporary mental incapacity, he/she is responsible for it, except for a person who proves that it is not their fault for entering such a mental state. If it is someone else's fault that person entered such a mental state, the person who caused it shall be the one responsible for damage."16"A minor by the age of seven is not responsible for damage. A minor from the age of seven

15 Taken from Art. 269 of the former Federal Obligatory Relations Act

16 Art. 1050 of the Obligation Relations Act of the Republic of Croatia. 
to the age of fourteen is not responsible for damage unless it is proven that he/ she was capable of reasoning at the moment of incurring damage. A minor after reaching fourteen years of age is responsible according to general rules on responsibility for damage." ${ }^{17}$

The injured party's guilt is not a presumption for the occurrence of shared responsibility for damage; it is the inadmissibility of conduct and the causality. In the case of the offender, all assumptions of responsibility for damage must be fulfilled: the existence of the offender and the injured party, the harmful act of the offender, damage, causal link between the harmful act and damage, and unlawfulness of the act. The former SFRY jurisprudence did not apply the rules on shared responsibility for damage if the offender intentionally caused damage. Later jurisprudence,even prior to the adoption of the Federal Obligation Relations Act and after that, began to apply shared responsibility even when the offender had acted intentionally (Kaladić, 2004: 113). Naturally, when it comes to determining damage compensation, it is important to note whether the offender acted with deliberation (dolus), extreme negligence (culpa lata), or just with ordinary negligence (culpa levis).From the quoted provisions of the Croatian Obligation Relations Act of the Republic of Croatia and the quoted provisions of the Obligation Relations Acts of some former SFRY states, it may be concluded that if it is possible to determine the amount of contribution of the injured party to resulting damage, i.e. the amount for which the compensation will be reduced; that reduction can be expressed as a percentage or as a fraction. On the other hand, when it is impossible to determine which part of damage stems from the injured party's actions or omissions, the court will award the compensation taking into account the circumstances of the particular case.

"The basis for reduction is the extent of the actual contribution of the injured party to the emergence or increase of damage, without taking into consideration intent or neglect as a weight. The assessment of the injured party's subjective bearing on the incidence or increase of damage is excluded. Only (un)usual behaviours and causality are established."(Crnić, 1987: 1049, 1050).

Shared responsibility for damage is also applied within the framework of objective responsibility for damage, which compares the significance of the injured party's contribution to damage and the significance of danger, i.e. dangerous activities. "Whether the offender is responsible on the basis of causation, i.e. in the framework of objective responsibility, the significance of the injured party's contribution to damage and the significance of danger, i.e. dangerous activities as a circumstance in relation to which the offender is responsible for damage occurrence is compared." If there is no actual damaging contribution of the

17 Art. 1051 of the Obligation Relations Act of the Republic of Croatia. 
injured party to his/her damage, the injured party's contribution will be less significant than the offender's contribution; thus, damage compensation will not be significantly reduced. If there is a more significant contribution of the injured party to his/her damage, the damage could be equally divided between the injured party and the offender. If there is an extraordinarily significant contribution of the injured party to his/her damage, the injured party should receive only a relatively small portion of the compensation. If guilt is also determined for the offender, it will not be neglected but will, to some extent, depending on its degree, reduce the significance of the injured party's contribution in determining the key for the distribution of damages " (Kaladić 2004: 114).

\section{Conclusion}

Although not existent in the Roman law, shared responsibility for damage today is an indisputable institute in all contemporary civil law systems. The largest number of observed civil law remedies mention guilt of the injured party as a cause of his/her co-responsibility for damage. The laws of states created from the former SFRY emphasize the damage caused to the injured party through his/her detrimental behaviour, which seems more acceptable than the injured party's guilt. Since these regulations do not regulate shared responsibility for damages in detail or precisely, judicial practice has a complex task to build up the criteria for measuring the contribution of the injured party to his/her own damage.

Shared responsibilities could also be regulated by special regulations (lex specialis) in particular areas (such as: traffic, dangerous substances, dangerous activities), as it is prescribed in some countries (for example, in France and Switzerland). In that case, the provisions could be more specific and more substantive in relation to general regulations that mainly contain only the basic provisions on shared responsibility for damage.

\section{References}

Blagojević, B.- Krulj, V. (1980). Komentar Zakona o obligacionim odnosima). Beograd

Crnić, J. (1987). Odgovornost više osoba za štetu i podijeljena odgovornost. Naša zakonitost. 9-10(XLI). 1040-1053

Gorenc, V. (2005). Komentar Zakona o obveznim odnosima). Zagreb

Kaladić, I. (2004). Podijeljena odgovornost za štetu). Zagreb

Keller, A. (1993). Haftpflicht im Privatrecht. Bern 
Koziol, H. (1986). Österreichisches Haftpflichtrecht. Wien

Larenz, K. (1982). Lehrbuch des Schuldrechts. Mùnchen

Mazeaud, H.- Tunc, L. (1970). Traité théorique et pratique de la responsabilité civile délictuelle et contractuelle. Paris

Planiol, M.- Ripert, G. (1952). Traité pratique de droit civil français. Paris

Rummel, P. (1992). Kommentar zum Allgemeinen bùrgerlichen Gesetzbuch. Wien

Tuhr, A. (1974). Allgemeiner Teil des Schweizerischen Obligationenreckts. Zürich

\author{
Др Владо Белај, \\ Редовни професор, \\ Правни факултет Свеучилишта J. J. Строссмауер у Осијеку \\ Иван Белај, маг јур., \\ Предавач, \\ Велеучилиште "Лавослав Ружичка" Вуковар \\ Република Хрватска
}

\title{
ДОПРИНОС ОШТЕТЕНИКА ВЛАСТИТОЈ ШТЕТИ
}

\section{Резиме}

Допринос оштећеника властитој штети или подијељена одговорност за штету подразумијева да је штета настала не само штетниковом радњом него да јој је допринио и оштећеник. Тада је потребно и при поправљању штете то узети у обзир, односно подијелити одговорност за штету између штетника и оштећеника. У римском праву није постојала подијељена одговорност за штету, а допринос оштећеника властитој штети регулиран је тек доношењем најзначајнијих грађанских законика. У правној теорији и законима појединих држава користе се различити називи за подијељену одговорност за штету. Такођер је спорно да ли се одговорност оштећеника темељи на кривњи или доприносу настанку штете. У раду се истражују законске и теоријске поставке подијељене одговорности за штету у упоредном праву с нагласком на најзначајније грађанскоправне режиме у свијету и грађанскоправне режиме неких држава бивше СФРЈ.

кључне ријечи: штета, штетник, оштећеник, кривња, допринос оштећеника, одговорност за штету, поправљање штете. 